\title{
TREND KURIKULUM DALAM PENDIDIKAN MATEMATIKA
}

\author{
Andes Safarandesa Asmara, Iwan Junaedi \\ andes@ubpkarawang.ac.id,iwanjunmat@gmail.com \\ Universitas Buana Perjuangan Karawang, Universitas Negeri Semarang
}

\begin{abstract}
The curriculum that applies to education is always changing according to the level of science needs and the world of the future. The curriculum is a set of rules and procedures in conducting education or in the broad sense contains the meaning related to the purpose and content of mathematics education and the means to achieve that goal. (ICMI, 1997). The purpose of this article is to know the trend of national and international curriculum in example through France. The applicable 2013 curriculum in Indonesia emphasizes the components of observing, questioning, trying, processing, presenting, summarizing and creating what is called the scientific aproach. These components should be generated in every learning process. While almost all formal education systems in France are implemented in a strictly centralized and controlled by the Ministry of Education Tadjab, and the distinctive features of the curriculum (1994: 99). Thus, in terms of the similarities and differences of the prevailing educational system, there is overall a relationship and has many similarities between education in Indonesia and France.
\end{abstract}

Keywords: Curriculum, Mathematics Education

\begin{abstract}
Abstrak: Kurikulum yang berlaku untuk pendidikan selalu berubah sesuai dengan tingkat kebutuhan ilmu dan dunia masa depan.kurikulum adalah seperangkat aturan dan tatacara dalam melakukan pendidikan atau dalam arti luas mengandung arti hal yang berkaitan dengan tujuan dan isi pendidikan matematika serta sarana untuk mencapai tujuan tersebut. (ICMI,1997). Tujuan dari artikel ini adalah ingin mngetahui trend kurikulum nasional maupun internasional yang di contohkan memalui negara Perancis. Kurikulum 2013 yang berlaku di Indonesia menekankan komponen mengamati, menanya, mencoba, mengolah, menyajikan, menyimpulkan serta mencipta yang disebut pendekatan ilmiah (scientific Aproach). Komponenkomponen tersebut seyogyanya dapat di munculkan pada setiap proses pembelajaran. Sedangkan hampir seluruh sistem pendidikan formal di Perancis dilaksanakan secara tersentralisasi yang ketat dan dikontrol oleh Kementerian Pendidikan Tadjab, dan ciri yang khas dari kurikulum (1994: 99). Maka di dapat persamaan dan perbedaan dari sistem pendidikan yang berlaku, namun secara keseluruhan terdapat hubungan dan memiliki banyak kesamaan antar pendidikan yang ada di Indonesia dan Perancis.
\end{abstract}

Kata kunci: Kurikulum, Pendidikan Matematika. 


\section{PENDAHULUAN}

Pendidikan dalam sejarah peradaban manusia merupakan komponen kehidupan yang paling penting. Semenjak manusia berinteraksi dengan aktifitas pendidikan, semenjak itu pula lah manusia telah berhasil merealisasikan berbagai perkembangan dan kemajuan dalam segala lini kehidupan. Secara paralel proses pendidikan pun mengalami kemajuan yang pesat, baik dalam bentuk metode, sarana, maupun target yang akan di capai. Karena hal ini merupakan salah satu sifat dan keistimewaan dari pendidikan, yaitu selalu bersifat maju. Ilmu pengetahuan dan teknologi mempengaruhi perkembangan dan perubahan pendidikan, khususnya perubahan pendidikan matematika. Pendidikan matematika dikatakan berkembang seiring dengan perkembangan teori belajar, teknologi, dan tuntutan dalam kehidupan. Perubahan yang terjadi sejak tahun 1980-an berawal dari Negara-negara seperti Amerika Serikat, Belanda, Perancis, Australia dan Inggris (Lange, 1995).

Matematika merupakan salah satu cabang pengetahuan yang memberikan kontribusi besar dalam perubahan pendidikan. Mengingat besarnya peran matematika dalam mengubah peradaban manusia, matematika menjadi suatu cabang ilmu yang harus di kuasai oleh siswa mulai dari tingkat sekolah dasar sampai perguruan tinggi. Salah satu tujuan pembelajaran dari sekolah dasar sampai perguruan tinggi adalah mengembangkan dan meningkatkan kapasitas intelektual siswa, sehingga dengan kualitas yang meningkat diharapkan mutu pendidikan pun meningkat (Kusmaryono, 2014).

Trend kurikulum matematika yang berlaku saat ini meliputi tiga komponen, yaitu: (1) penggunaan berbagai aplikasi; (2) unit baru dari ilmu matematika; dan (3) penggunaan komputer (Hilton). Hal ini sejalan dengan Kurikulum 13 yang berlaku di Indonesia saat yang menekankan pada sistem pendidikan karakter. Pendidikan karakter tersebut meliputi tiga tahap, yaitu: (1) input, meliputi pengintegrasian tri pusat pendidikan (sekolah, orang tua dan masyarakat) dengan intrakulikuler, kokulikuler, ekstrakulikuler dan hidden curriculum di sekolah; (2) proses yang terdiri dari penguatan nilai-nilai karakter, berupa olahraga (kinestetika), olah hati (etika), olah pikir (literasi) dan olah karsa (estetika; (3) output, untuk membangun generasi emas 2045 dengan dibekali karakter, literasi, dan keterampilan abad 21. 
Keterampilan abad 21 mempunyai tiga domain kompetensi menurut NRC (National Research Council), yaitu: kognitif, intrapersonal dan interpersonal. Domain kognitif meliputi penalaran dan memori, domain intarpersonal meliputi fungsi eksekutif (metakognitif) dan emosi, dan interpersonal meliputi menyatakan ide/pendapat, interpretasi dan mampu menjawab pesan dari yang lain Pellegrina dan Hilton, 2012). Maka untuk menjawab tantangan tersebut digunakan lah pendekatan-pendaktan dalam proses pembelajaran untuk memungkinkan tercapainya pendidikan karakter.

Pendekatan ilmiah (saintifik) menjadi ciri khas dari pelaksanaan kurikulum. Kemendikbud (2013) memberikan pengertian tersendiri tentang pendekatan ilmiah (scientific Aproach) dalam pembelajaran, yang di dalamnya mencakup komponen mengamati, menanya, mencoba, mengolah, menyajikan, menyimpulkan serta mencipta. Komponen-komponen tersebut seyogyanya dapat di munculkan pada setiap proses pembelajaran.

Kenyataan belum signifikan terjadi perubahan dalam pembelajaran matematika di Indonesia, hal ini karena masih lemahnya proses belajar mengajar yang dilakukan oleh guru di kelas, dan juga di perparah dengan evaluasi yang kadang hanya mengukur hapalan teoritis. Hal ini terbukti dengan survey yang di lakukan oleh PISA (Programme International for Student Assesment) yang menyatakan bahwa kemampuan matematika siswa Indonesia masih rendah, hal ini dapat terlihat bahwa Indonesia selalu menempati peringkat 10 negara terbawah (OECD, 2014).

Di dasarkan pada data tersebut, bahwa Indonesia masih butuh rujukan atau referensi yang mampu membuat sistem pendidikan kita lebih maju lagi. Untuk itu maka kita perlu mencari rujukan-rujukan tentang perkembangan pendidikan, khususnya pendidikan matematika di Negara maju. Menurut Tadjab (1994), ketika seseorang akan studi perbandingan maka sistem pendidikan nasional negara Perancis, Inggris dan Amerika Serikat sebagai sasaran studi. Karena sistem pendidikan negara Perancis dianggap sebagai wakil istimewa dari tradisi pendidikan daratan Eropa dengan seleksinya yang ketat di bidang pendidikan menengah. Yang menjadi pusat perhatian dalam studi ini, hanyalah beberapa aspek penting dari sistem pendidikan negara Prancis. 


\section{TREND KURIKULUM}

Kurikulum matematika sekolah mengalami perubahan yang luar biasa dalam 20 tahun terakhir. Salah satu perubahan yang paling terlihat di banyak negara adalah pengurangan jam dikhususkan untuk matematika dan ilmu pengetahuan. Misalnya Perancis, sampai tahun 1994 sekolah menengah (Lycee) siswa memiliki 15 jam mengajar sains perminggu, 9 jam untuk matematika dan fisika. Tahun 1999, hanya 8 jam untuk mengajar matematika, fisika, biologi dan teknologi. Karena seringnya perubahan kurikulum yang terjadi maka kadang-kadang universitas pencetak guru tidak merasa ada perubahan dalam materi, sehingga kadang-kadang calon guru yang dihasilkan tidak optimal. Walaupun bukan satu-satunya alasan untuk tidak merubah kurikulum yang ada. Perubahan kurikulum di lakukan untuk mengatasi perkembangan ilmu pengetahuan yang sangat pesat, jika tidak di ubah malah di mungkinkan suatu negara teringgal.

\section{CONTOH KURIKULUM NASIONAL DAN INTERNASIONAL}

\section{Terbentuknya Pendidikan di Perancis}

Sejarah menceritakan kenapa Prancis sangat bersifat sentralistis dan birokratis dalam bentuk pemerintahan dan pendidikannya. Dunia sepertinya telah membangunkan raksasa tidur karena, (1) pembukaan sekolah menengah dan universitas bagi siswa-siswa baru, yang mayoritas berasal dari kelompok sosial yang dulunya tidak pernah dapat tempat; (2) karena adanya reformasi yang terusmenerus yang selama ini tidak bisa diterima oleh pihak-pihak penguasa menurut J.C.Eicher, 1995 (Syah Nur, 2001: 200).

Perancis tergolong negara yang telah maju industrinya di antara negara maju di Barat lainnya. Problema-problema yang dirasa belum dapat diselesaikan secara tuntas adalah yang menyangkut masalah kependidikan dari abad ke abad. Sebelum pecah revolusi tahun 1789, pendidikan di Perancis berada di tangan Gereja Katholik atau yang berkaitan dengan Gereja. Sejak permulaan abad ke 18 boleh dikatakan masyarakat/bangsa Perancis secara kultural terbagi dua golongan yaitu: (1) Golongan Katholik yang pada umumnya tradisional; dan (2) Golongan sekuler yang berjiwa revolusioner. 
Sistem kependidikan berubah dari satu kurun waktu sebelum Perang Dunia II sampai sesudah Perang Dunia II. Akan tetapi sampai sekarang yang dijadikan prinsip kependidikan di Perancis ialah cetusan ide revolusi tahun 1789 yang berintikan pada semboyan politik revolusi yaitu: Liberte (kebebasan), Egalite (persamaan) dan Fraternite (persaudaraan) (Arifin, 2003:84). Namun semboyan yang ideal itu bagi rakyat Perancis tidaklah mudah untuk direalisasikan dalam program pendidikan, akibat kurang adanya kesamaan langkah dari kalangan pemimpin masyarakat dan pemerintahan.

Tadjab (1994:98) menyatakan ide pendidikan yang bersifat sentralisasi, timbul atas usul Condercet tahun 1792, agar diadakan suatu sistem pendidikan untuk semua orang, yang disebar luaskan ke seluruh komunitas, yang akan merupakan dasar bagi suatu piramida susunan pendidikan dengan universitas-universitas dan Kementrian Pendidikan sebagai puncaknya. Pada tahun 1808 Napoleon Bonaparte mengambil alih masalah pengelolaan kependidikan di negerinya dengan mendirikan apa yang disebut "Universitie Imperiali de France" (Universitas Kerajaan Perancis), yang pengertiannya berbeda dengan arti universitas pada umumnya. Karena istilah itu mengandung arti pembagian wilayah Perancis menjadi "daerah-daerah kependidikan" yang masing-masing disebut "Academic" yang memiliki satu universitas sebagai pusatnya. Presiden universitas itulah yang mengepalai daerah kependidikan yang disebut "academic" yang menjadi bawahan langsung dari kantor pusatnya di Paris (Arifin, 2003:84).

Dengan demikian, Academic mempunyai satu universitas sebagai pusatnya, dan Presiden universitas inilah yang bertanggu jawab atas segala sesuatu yang berkenaan dengan pendidikan, pengajaran menengah tinggi. Menurut Tadjab, monopoli pendidikan oleh negara, yang dimulai oleh Napoleon ini berakhir tahun 1850, dengan diperkenankannya perguruan-perguruan swasta berdiri. Dimana sampai saat ini ciri dan jiwa organisasi ciptaan Napoleon masih terus berlaku, dan sistem sentralisasi inilah yang merupakan ciri yang paling khas dari sistem pendidikan Prancis. (Tadjab, 994:99)

\section{Jenjang Pendidikan Prancis}


Tujuan utama pendidikan Perancis pada mulanya adalah untuk meningkatkan nasionalisme. Upaya peningkatan nasionalisme ini dilakukan melalui sekolah dengan mempromosikan buku-buku teks yang seragam isinya antara lain menekankan perlunya melanjutkan negara Perancis yang sudah ada semenjak rezim lama (kerajaan) dan pembentukan sistem baru bersifat sentralistis yang ketat. Hampir seluruh sistem pendidikan formal di Perancis dilaksanakan secara tersentralisasi yang ketat dan dikontrol oleh Kementerian Pendidikan. Tadjab (1994:99) mengemukakan jenjang pendidikan di negara Perancis terdiri atas tiga, yaitu:

1. Pendidikan Dasar (pra-sekolah dan sekolah rendah).

2. Pendidikan Menengah (pendidikan menengah umum dan kejuruan)

3. Pendidikan Tinggi (berbagai jurusan).

\section{Kurikulum Berdasarkan Jenjang Pendidikan di Prancis}

\section{Pendidikan Dasar Prancis}

Di Prancis tingkat Sekolah Dasar (SD) yang pendidikannya adalah gratis, wajib, dan tidak membedakan aliran keagamaan. Siswa sekolah dasar ini dari umur 6 sampai 11 tahun. Kurikulum pendidikan rendah (pendidikan dasar) terdiri atas: bahasa Prancis, membaca dan menulis, berhitung, sejarah dan ilmu bumi, pelajaran budi pekerti dan kewarganegaraan, dasar-dasar ilmu pasti dan alam, dasar-dasar menggambar, pekerjaan tangan, bernyanyi dan gerak badan (Tadjab,1994:100). Pelajaran di tingkat ini sama bagi semua anak, baik laki-laki maupun perempuan. Namun sebelum memasuki sekolah rendah itu, anak-anak memasuki pendidikan pra-sekolah, yang disebut "ecoles maternelles" atau sekolah ibu, mulai umur 2 tahun. Pusat perhatian pendidikan pra-sekolah ini, adalah perkembangan fisik, intelek dan moral anak. Untuk mencapai tujuan tersebut kurikulumnya terdiri atas gerak badan, bermain-main, bernyanyi, menggambar dan melukis serta membuat barang-barang dengan tangan; dan diadakan latihan observasi terhadap bendabenda yang ada disekitar lingkungan anak.

Pada tahun terakhir anak-anak pra-sekolah mulai diperkenalkan dengan pelajaran membaca, menulis dan berhitung. Pendidikan rendah dibagi atas 3 bagian, yaitu: 
a. Persiapan, bagi anak yang berumur 6 sampai 7 tahun.

b. Elementer, bagi anak yang berumur 7 sampai 9 tahun.

c. Pertengahan, bagi anak yang berumur 9 sampai 11 tahun.

\section{Pendidikan Menengah Prancis}

Pendidikan menengah di Prancis, dimulai dengan memasuki kelas percobaan (cycle d'observation), yang pada masa lalu, melalui seleksi yang ketat; tetapi sekarang semua yang lulus sekolah dasar negeri yang memenuhi syarat dapat memasuki kelas ini tanpa seleksi. Yang diterima pada kelas percobaan ini ialah anak yang berumur paling sedikit 11 tahun dan tidak lebih dari 12 tahun (Tadjab,1994:100). Setelah anak menyelesaikan cycle d'observation yang lamanya 2 tahun ini, terbukalah 5 jenis pendidikan bagi anak sesuai dengan bakat dan kemampuannya. Jenis pertama adalah Pendidikan Penutupan, yang lamanya 3 tahun dan tidak ada lanjutannya. Kurikulumnya adalah merupakan lanjutan dari pendidikan umum sekolah dasar dan ditambah dengan mata pelajaran praktis untuk kehidupan sehari-hari. Pendidikan ini dimaksudkan bagi anak-anak yang bakatnya paling tipis dan yang kemampuan intelektualnya paling rendah.

Dengan berlakunya Undang-undang wajib belajar sampai umur 16 tahun, maka pendidikan ini di akhiri dengan ujian dan ijazah pendidikan wajib. Jenis kedua adalah Pendidikan Umum Pendek, yang disebut juga dengan sekolah Menengah Umum, yang lamanya 3 tahun. Lulusan pendidikan umum ini, dapat memasuki jabatan-jabatan yang tidak bersifat teknis dan bisa memasuki Sekolah Normal (Guru). Jenis ketiga adalah Pendidikan Kejuruan Pendek, yang diberikan dalam Sekolah Menengah Kejuruan, yang lamanya 4 tahun. Pendidikan ini dimaksudkan bagi anak-anak yang berbakat teknis. Disamping memperluas pendidikan umum, pendidikan ini meliputi latihan teori dan praktek dalam suatu kejuruan dan juga diberikan spesialisasi agak mendalam.

Jenis keempat adalah Pendidikan Kejuruan Panjang, yang diperuntukan bagi mereka yang berbakat teknis yang mempunyai kemampuan intelektual tinggi. Pendidikan ini terdiri dari pendidikan agen teknik, selama 4 tahun dan pendidikan ahli selama 5 tahun. Jenis kelima adalah Pendidikan Umum Panjang, yang menyiapkan anak atau lulusannya untuk memasuki pendidikan tinggi. Lama 
pendidikannya adalah 7 tahun, termasuk masa penentuan jurusan (kelas percobaan) (Tadjab, 1994: 100).

\section{Pendidikan Tinggi Prancis}

Jenjang pendidikan tinggi, diberikan di universitas-universitas. Universitas Sarbonne di Paris adalah Universitas Pusat. Disetiap academie ada sebuah universitas sebagai pusat. Setiap universitas, baik di pusat, maupun yang di academie-academie, terdiri dari sejumlah fakultas. Suatu universitas dapat juga meliputi lembaga-lembaga yang meliputi suatu akademi dalam ilmu-ilmu tertentu. Fakultas atau institut penelitian atau sekolah tinggi yang menjadi bagian dari suatu universitas, mempunyai otonomi yang luas; dan mempunyai fasilitas-fasilitas sendiri seperti laboratorium dan perpustakaan. Universitas Paris misalnya; mempunyai lebih dari 100 perpustakaan khusus dalam bidang-bidang tertentu dan tersebar di berbagai tempat (Tadjab, 1994: 101).

Pendidikan Tinggi (universitas), dibagi dalam 3 cycle, masing-masing 2 tahun lamanya dan diakhiri dengan ujian.

a. Cycle pertama mengenai "science" terdiri dari 4 jurusan yang dapat dipilih mahasiswa. Kalau lulus ujian pada cycle science ini, mahasiswa mendapat ijazah

D.U.E.S. dan diberi kesempatan untuk melanjutkan ke institusi lain, atau akan terus belajar pada universitas yang sama.

b. Cycle kedua mengenai kesenian, mempunyai 5 jurusan, untuk mahasiswa yang tidak ingin menjadi guru. Yang lulus ujian akhir cycle kesenian ini mendapat ijazah D.U.E.L.

c. Cycle ketiga, ditujukan untuk menghasilkan para peneliti dengan gelar "maitreise". Bagian science terdiri dari 12 jurusan. Selama cycle ini, mahasiswa bagian science harus mendapatkan 4 ijazah (2 ijazah) setiap tahun, sedangkan bagian kesenian 2 ijazah. Untuk mendapatkan gelar "maitrase" seorang mahasiswa harus membuat tesis; pada akhir tahun ketiga diberi ijazah "licence", yang menghendaki pengkhususan dalam satu atau dua mata pelajaran di sekolah. Ijazah untuk menjadi guru Lycee diperoleh setelah menamatkan IPES (Institut de Preparation Aux Enseignenments Du Second Degree), dan 
menempuh ujian negara yang diadakan tiap tahun dan bersifat kompetitif dan selektif. Pada akhir cycle ketiga, mahasiswa yang lulus ujian, mendapat gelar doktor (Tadjab,1994:102).

Sekolah normal diadakan untuk pendidikan guru, yang disebut "Ecole Normale". Sekolah Normal ini dalam setiap wilayah (academie) ada dua buah, satu untuk pria dan lainnya untuk wanita yang diterima adalah anak-anak berumur antara 15-17 tahun dan lulus ujian masuk; mereka sekurang-kurangnya harus sudah tamat kelas III sekolah menengah. Lama belajarnya 4 tahun, 3 tahun pertama untuk melengkapi pendidikan calon guru sampai tingkat baccalaureat dan pada tahun keempat untuk pendidikan keguruan serta prakteknya. Sedangkan untuk sekolah guru menengah (lycee) harus mendapatkan pendidikan di perguruan tinggi dan IPES sebagaimana telah dikemukakan. Beberapa lulusan menengah yang terbaik dalam ujian masuk, dapat diterima di Sekolah Normal Tinggi (Ecole Normale Superieur), yang merupakan salah satu bentuk "Grand Ecole" atau sekolah tinggi bukan universitas. Oleh karena lulusan Grand Ecole ini terjamin kedudukannya setelah tamat, bebas uang kuliah, malahan diberi uang pemondokan dan uang saku, maka banyak sekali yang ingin masuk, tetapi tempatnya sangat terbatas; karenanya ujian masuk diperberat.

\section{Jenjang Pendidikan Indonesia}

Berdasarkan UU Sisdiknas No.20 Tahun 2003, jenjang pendidikan di Indonesia ada 3 yaitu;

a. Pendidikan Dasar (SD, MI, MTS dan SMP)

b. Pendidikan Menengah (SMA, MA, SMK, MAK)

c. Pendidikan Tinggi (Akademi, Politeknik, Sekolah tinggi, Institut, atau Universitas)

\section{Kurikulum Berdasarkan Jenjang Pendidikan di Indonesia}

\section{Pendidikan Dasar Indonesia}

Pendidikan Dasar di Indonesia, dimulai dengan jenjang pendidikan yang pertama yaitu: Pendidikan Anak Usia Dini. Pendidikan Anak Usia Dini (PAUD) adalah suatu upaya pembinaan yang ditujukan bagi anak sejak lahir sampai dengan usia enam tahun yang dilakukan melalui pemberian rangsangan pendidikan untuk 
membantu pertumbuhan dan perkembangan jasmani dan rohani agar anak memiliki kesiapan dalam memasuki pendidikan lebih lanjut. Pendidikan anak usia dini diselenggarakan sebelum jenjang pendidikan dasar. Pendidikan Anak Usia Dini dapat diselenggarakan melalui jalur pendidikan formal, nonformal, dan/atau informal (UU, Sisdiknas, pasal 28; 2003).

Menurut Sisdiknas Pasal 28 ayat 3, Pendidikan anak usia dini pada jalur pendidikan formal berbentuk:

a. Taman Kanak-kanak (TK),

b. Raudatul Athfal (RA), atau bentuk lain yang sederajat.

Di Indonesia Pendidikan dasar merupakan jenjang pendidikan yang melandasi jenjang pendidikan menengah. Setiap warga negara yang berusia tujuh sampai dengan lima belas tahun wajib mengikuti pendidikan dasar. Pemerintah dan Pemerintah Daerah menjamin terselenggaranya wajib belajar bagi setiap warga negara yang berusia 7 (tujuh) tahun pada jenjang pendidikan dasar tanpa memungut biaya.

Kurikulum pendidikan dasar dan menengah wajib memuat; pendidikan agama, pendidikan kewarganegaraan, bahasa, matematika, ilmu pengetahuan alam, ilmu pengetahuan sosial, seni dan budaya, pendidikan jasmani dan olah raga, keterampilan/kejuruan dan muatan lokal (UU, Sisdiknas, pasal 37:2003).

\section{Pendidikan Menengah Indonesia}

Di Indonesia pendidikan menengah juga terdiri dari beberapa jenis pendidikan. Pendidikan Menengah merupakan lanjutan dari pendidikan dasar. Pendidikan menengah terdiri atas:'

a. Pendidikan menengah umum (SMA, MA) dan

b. Pendidikan menengah kejuruan (SMK, MAK).

Pendidikan umum merupakan pendidikan dasar dan menengah yang mengutamakan perluasan pengetahuan yang diperlukan oleh peserta didik untuk melanjutkan pendidikan ke jenjang yang lebih tinggi. Sedangkan, pendidikan kejuruan merupakan pendidikan menengah yang mempersiapkan peserta didik terutama untuk bekerja dalam bidang tertentu. Pendidikan menengah umum maupun kejuruan lama pendidikannya 3 tahun (sisdiknas, pasal 15, 2003). 
Kurikulum Pendidikan Menengah wajib memuat; pendidikan agama, pendidikan kewarganegaraan, bahasa, matematika, ilmu pengetahuan alam, ilmu pengetahuan sosial, seni dan budaya, pendidikan jasmani dan olah raga, keterampilan/kejuruan dan muatan lokal (UU, Sisdiknas, pasal 37:2003).

\section{Pendidikan Tinggi Indonesia}

Jenjang Pendidikan Tinggi di Indonesia terdiri dari beberapa macam dimana, pendidikan tinggi merupakan jenjang pendidikan setelah pendidikan menengah yang mencakup program pendidikan diploma, sarjana, magister, spesialis, dan doktor yang diselenggarakan oleh perguruan tinggi (UU, Sisdiknas, pasal 19: 2003). Dan dapat berbentuk (Akademi, Politeknik, Sekolah tinggi, Institut, atau Universitas).

Perguruan tinggi berkewajiban menyelenggarakan pendidikan, penelitian, dan pengabdian kepada masyarakat. Perguruan tinggi dapat menyelenggarakan program akademik, profesi, dan/atau vokasi (UU, Sisdiknas, pasal 20, 2003). Kerangka dasar dan struktur kurikulum Pendidikan Tinggi di Indonesia dikembangkan oleh perguruan tinggi yang bersangkutan dengan mengacu pada standar nasional pendidikan untuk setiap program studi. Dimana kurikulum pendidikan tinggi wajib memuat: pendidikan agama, pendidikan kewarganegaraan dan bahasa.

\section{Analisis Aspek Jenjang dan Kurikulum Pendidikan Prancis dan Indonesia.}

Berdasarkan data diatas jika dilihat pendidikan dasar antara Indonesia dan Prancis terdapat perbedaan dalam hal pembagian jenjangnya, jika di Indonesia pendidikan dasar meliputi Sekolah Dasar (SD) dan Sekolah Menegah Pertama (SMP) dengan tingkat usia peserta didik 7-15 tahun wajib mengenyam pendidikan, untuk mendukung program pemerintah yaitu, terselenggaranya wajib belajar bagi setiap warga negara. Sedangkan di Perancis Pendidikan Dasar terbagi lagi dalam 3 tingkatan, di mana sistem pendidikan memiliki aturan untuk menjamin bahwa semua siswa wajib memperoleh satu batang kompetensi dan pengetahuan dalam tujuh domain berikut: Bahasa Perancis, Satu bahasa asing lainnya, Matematika dan ilmu Sastra, Informasi dan Teknologi, Ilmu Sosial dan Kewarganegaraan, Semangat otonomi dan inisiatif. 
Sedangkan pada Pendidikan Menengah, sistem pendidikan antara Indonesia dan Prancis banyak terdapat perbedaan. Untuk pendidikan menengah Indonesia lama pendidikan dapat diselesaikan dalam jangka waktu 3 tahun. Sementara pada sistem pendidikan Prancis masih terdapat 5 jenis pendidikan bagi siswa yang disesuaikan dengan bakat dan kemampuannya. Lama pendidikan yang ditempuh sesuai dengan jenis pendidikan yang dipilih, rata-rata waktu pendidikan ada yang 3 tahun, 4 tahun bahkan sampai 7 tahun. Ini menunjukan adanya perbedaan antara pendidikan menengah antara Indonesia dan Perancis. Demikian juga pada kurikulumnya di Prancis sudah terspesifikasi dalam satu bidang ilmu yang akan digeluti sesuai dengan kemampuan siswa itu sendiri. Sementara di Indonesia ada dua pendidikan menengah yang bisa dipilih oleh siswa sesuai dengan kemampuannya, baik untuk pendidikan umum maupun pendidikan kejuruan.

Terdapat perbedaan-perbedaan sistem pendidikan tinggi di Indonesia dan Prancis, di Prancis untuk memperoleh pendidikan tinggi harus mengikuti beberapa tahapan yang pada akhirnya akan mendapatkan gelar setelah mengikuti ujian negara sesuai dengan jurusan yang di pilih mahasiswa sementara mengenai kurikulum pendidikan tinggi secara keseluruhan bersifat sentralisasi yang diatur oleh sebuah komisi nasional pendidikan. Di Indonesia pun demikian juga bahwa pendidikan tinggi terdiri dari berbagai bentuk baik akademi, politeknik, sekolah tinggi, institut, atau universitas namun pada persoalan kurikulum pendidikan tinggi Indonesia memiliki wewenang dalam hal penyelanggaraan pendidikan, hal ini terlihat pada kurikulum pendidikan tinggi yang dikembangkan oleh perguruan tinggi dengan mengacu pada standar nasional pendidikan. Jadi terdapat perbedaan antara pendidikan tinggi Indonesia dan Perancis terutama dalam hal penyelenggaraan kurikulum.

Penyelenggaraan kurikulum yang berbeda, namun ketika dilihat pada saat penggunaan aplikasi, komputasi dan teknologi informasi kedua negara tersebut sudah menggunakan aplikasi tersebut secara optimal untuk proses pembelajaran sesuia dengan trend matematika saat ini. Hal ini terlihat jelas dari kurikulum yang di sampaikan oleh kedua negara tersebut. Berbeda dengan trend kurikulum matematika lalu yang kegunaan matematika hanya panduan teks, untuk 
menggambarkan teks, untuk menginterpretasikan sebuah teks dan berpartisipasi dalam sebuah konteks (Remillard, 2005).

\section{PENUTUP}

Berdasarkan pembahasan di atas, maka dapat di simpulkan bahwa:

1. Sistem pendidikan Indonesia dan Prancis pada pembagian jenis dan jenjang pendidikannya hampir memiliki kesamaan mulai dari:

a. pendidikan dasar (pendidikan pra-sekolah dan sekolah dasar)

b. pendidikan menengah (pendidikan menengah umum dan kejuruan), dan

c. pendidikan tinggi yang terdiri dari berbagai jenis jurusan, hanya saja terdapat perbedaan dalam tahapan penerimaan mahasiswa pada pendidikan tinggi.

2. Prancis sistem pendidikan bersifat sentralistis, maka pengembangan kurikulum sekolah diatur oleh sebuah komisi nasional beranggotakan korp Inspektur Jendral. Cakupan kurikulum bersifat nasional dan sedikit sekali peluang yang diberikan untuk muatan lokal daerah.

3. Indonesia sistem pendidikan Indonesia bersifat desentralisasi, walaupun masih ada hal-hal tertentu yang bersifat sentralisasi, contohnya ujian nasional. Namun pelaksanaan kegiatan pendidikan dalam satuan pendidikan didasarkan atas kurikulum yang berlaku secara nasional dan kurikulum yang disesuaikan.

Simpulan di atas menunjukan bahwa sebetulnya sistem pendidikan di Negara maju (Perancis) dan Negara berkembang (Indonesia) memiliki kesamaan dalam prosesnya, walaupun ada juga perbedaan, maka berdasarkan hal itu ada beberapa saran yang dapat penulis tuturkan, yaitu:

1. Karena banyaknya kesaaman dalam sistem pendidikan, maka dalam hal ini perancis dapat menjadi rujukan untuk referensi proses pembelajaran.

2. Untuk guru yang ingin mengembangkan assesmen tentang penilaian terpadu, Negara perancis dapat dijadikan rujukan karena kurikulum yang berlaku disana bersifat nasional sehingga kemungkinan keterpaduannya tinggi, dibandingkan dengan kurikulum yang desentarlisasi. 


\section{DAFTAR RUJUKAN}

Arifin. (2003). Ilmu Perbandingan Pendidikan. Cetakan ke 6. Jakarta: Golden Terayon Press.

Berliner, D.C. (2001). Learning About and learning From Expert teacher. International journal of Edcutaional Research. 35(5), 463-482.

Bromme, R. (2001). Teacher Expertise. Internationa encyclopedia of the social and behavioral science. Amsterdam: Smlser and Baltes, 15459-15465.

Departemen Pendidiksn Nasional Republik Indonesia. (2003). Undang-Undang Republik Indonesia Nomor 20 Tahun 2003 Tentang system Pendidikan Nasional. Jakarta.

Guerriero, S. (2017). Pedagogical Knowledge and The Changing Nature of The Teaching Profession. OECD Publishing. Paris.

Hasan, Hamid. (2001). Pendekatan Multikultural untuk Penyempurnaan Kurikulum Nasional.http//www.pdk.go.id/balitbang/publikasi/jurnal/No._026/pendekat an_hamid_hasan.

Hillel, Joel. 2001. The Teaching and Learning of Mathematics at University Level: An ICMI Study. Kluwer Academic Publishers. Printed in the Netherlands, 5969.

Hilton, J. Peter. (...). Current Trends in Mathematics and Future Trends in mathetaics Education. State University of New York. Binghamton.

Himpunan Perundang-Undangan RI Tentang sistem Pendidikan Nasional. (2003).

Kusmaryono, Imam. (2014). Tren Pendidikan Masa Kini. Makalah Disajikan Dalam Seminar Nasional PMAT_FKIP Unissula Semarang, 15 Nopember 2014.

Nur, Agustiar Syah. (2001). Perbandingan Sistem Pendidikan 15 Negara. Bandung: Lubuk Agung.

OECD. (2014). “PISA 2012” Results: What Students Know and Can Do”. OECD Publications, vol.1. (Februari 2014:5-61).

Pellegrina, J.W., and M. Hilton (eds). (2012). Education for Life and work: Developing Transferable Knowledge and Skills in the 21st Century. National Acdemic Press, Washington, DC.

Remilard, J.T. (2005). Examining key Concept in Research on Theacher Use of Mathematics Curicula. Review of Jurnal Eduaction Research. 75(2),21-216. 